Available for free online at https://ojs.hh.se/

Journal of Intelligence Studies in Business 2 (2012) 23-34

\title{
Synergy Between Competitive Intelligence and Knowledge Management - a key for Competitive Advantage
}

\author{
Jihene Chebbi Ghannay $^{1}$ and Zeineb Ben Ammar Mamlouk ${ }^{2}$ \\ ${ }^{1}$ ESCT, Tunis, Tunisie, Jihene.ghannay@yahoo.fr \\ ${ }^{2}$ ESSEC, Tunis, Tunisie, zeinebbenammar@yahoo.fr
}

Received 5 May, revised form 11 September, accepted 27 September 2012

\begin{abstract}
The market orientation perspective states that organizations have no option but to look beyond internal business activities and to integrate events from the external environment. These are complex, turbulent and rapidly changing. Firms today are led to utilize information and the knowledge of companies because to succeed in the information economy comes from harnessing these resources. Knowledge and information become strategic, paramount and must therefore be managed. Integrating knowledge management (KM) and competitive intelligence encourage the use of these resources, improve their quality and allow an enterprise to respond more rapidly to changing business conditions. The aim of this article, is to present similarities, differences, benefits of KM and CI for the organization through the study of current literature. Besides, we present critical success factors needed to achieve a successful implementation of these two processes, and further, highlight the importance of KM and CI integration for the organization to compete in the knowledge economy.
\end{abstract}

Keywords: Knowledge management, competitive intelligence, competitive advantage

\section{Introduction}

The globalization of markets accompanied by rapid change in information technology has increased the competitiveness in most industries. In the struggle to remain competitive, many companies have turned to new technologies to improve their business activities. This development is also true for information-related activities and will directly affect the development and quality of a firm's business and corporate level strategies. These activities are integrated in the CI and KM functions of the company. Deed and Hill (1996) argue that "firms that are acquiring knowledge will be able to create and sustain a competitive advantage in the knowledge-based economy. Those (firms) that are not will have difficulty maintaining their competitive position". CI has long been recognized as a strategic management tool and a fast growing field. CI is rapidly becoming a major technique for achieving competitive advantage (Davis, 2004). Essentially, CI involves the legal collection of information on competitors and the overall business 
environment. The knowledge gained from this information is used to enhance the organization's own competitiveness. As such, CI can also be viewed as a subset of $\mathrm{KM}$.

Organizations possess numerous resources, but it is the resources that are unique, inimitable, and valuable which are central to a competitive advantage (Barney, 1986, 1991; Prahalad and Hamel, 1990; Wernerfelt, 1984). An organization's knowledge is one such resource. According to Civi (2000) and Gupta, Iyer, and Aronson (2000), the only competitive advantage that organizations will have in the 21st century is what they know and how they use it. This is because the proper management and leveraging of knowledge can propel an organization to become more adaptive, innovative, intelligent and sustainable (Wong \& Aspinwall, 2004a).

In fact, KM has become an important strategy for improving organizational competitiveness and performance by applying it to production, marketing, research and development, personnel, planning and innovation. It is also considered as creating sustainable competitive advantage for organizations (King and Zeithaml, 2001; Johannessen and Olsen, 2003; Lado and Wilss, 1994; ofek and sarvary, 2001). Thus, the vision of $\mathrm{KM}$ is to improve a firm's competitive powers or to maintain a firm's competition powers. KM is the management of knowledge assets within an organization to enhance competitive power by steering product, leadership, operational excellence, and customer intimacy.

\section{Literature review}

\subsection{Defining CI}

$\mathrm{CI}$ is a current topic in the business world today. Hence, workshops, seminars, training courses and books have been increasing in numbers steadily since 1980 . CI has been reported as one of the fastest growing disciplines in the US (SCIP, 2000; Miller, 2000; Kahaner, 1998). The concept of $\mathrm{CI}$ is very vague, numerous definitions of CI available in literature are imprecise and inclusive, and the expression is often used integrally with other related concepts such as a business intelligence and competitor intelligence. Practitioners and theorists have largely failed to agree on a common definition of CI. Although, consensus about some aspects of the function have been achieved, Fuld \& Co., a high profile CI consulting firm, takes an inclusive approach in defining the function of CI thus: "competitive intelligence can mean many things to many people. A research scientist sees it as a heads-up on a competitor's new R\&D initiatives. A salesperson considers it as an insight on how his or her company should bid against another firm in order to win a contract. A senior manager believes intelligence to be a long-term place and its rivals" (Fuld \& Co, 2002).

The Society for Competitive Intelligence Professionals (SCIP), gives a more precise definition: "A systematic and ethical program for gathering, analyzing, and managing external information that can affect your company's plans, decisions, and operations. Put it another way, CI is the process of enhancing marketplace competitiveness through a greater-yet unequivocally ethical-understanding of a firm's competitors and the competitive environment" (SCIP Web site, 2002).

CI can be defined, also, as knowledge and foreknowledge about the external operating environment. The ultimate goal of each intelligence process is to facilitate decisionmaking that leads to action. "Competitive intelligence is a formalized, yet continuously evolving process by which the management team assesses the evolution of its industry and the capabilities and behavior of its current and potential competitors to assist in maintaining or developing a competitive advantage. (Prescott and Gibbons, 1996).

\subsection{KM definition}

$\mathrm{KM}$ is often viewed as multidimensional and multidisciplinary concept. There are many definitions of $\mathrm{KM}$ in the literature, thus comparisons must be made to know the focus by each author. Some of the focuses are highlighted below.

Professor Michael Sutton (2008) of the Gore School of Business at Westminster College reported at the ICKM (International Conference on Knowledge Management) meeting in 2008 that he had assembled a library of more than 100 of them (Mclnerney C and Koeing M, 2009). Three definitions of KM ones are presented here. At the very beginning of the KM movement, Davenport (1994) offered the following: "knowledge management is the process of capturing, distributing, and effectively using 
knowledge". This definition has the virtue of being simple, stark, and to the point. A few years later, the Gartner Group created another definition of KM, which is perhaps the most frequently cited (Duhon, 1998): “A discipline that promotes an integrated approach to identifying, capturing, evaluating, retrieving, and sharing all of an enterprise's information assets. These assets may include databases, documents, policies, procedures, and previously un-captured expertise and experience in individual workers”.

Finally, the definition given by Peter Drucker (1994), whom many consider as the father of $\mathrm{KM}$, defines the need for this function: "Knowledge has become the key resource, for a nation's military strength as well as for its economic strength (...) is fundamentally different from the traditional key resources of the economist — land, labor, and even capital (...) We need systematic work on the quality of knowledge and the productivity of knowledge (...) the performance capacity, if not the survival, of any organization in the knowledge society will come increasingly to depend on those two factors".

\section{CI and KM processes}

\subsection{CI process}

The CI process consists of the following steps: monitoring business environment (external data, information and knowledge), gathering, analyzing, filtering and disseminating intelligence that will support decision making process in order to increase competitiveness and improve position of organization.

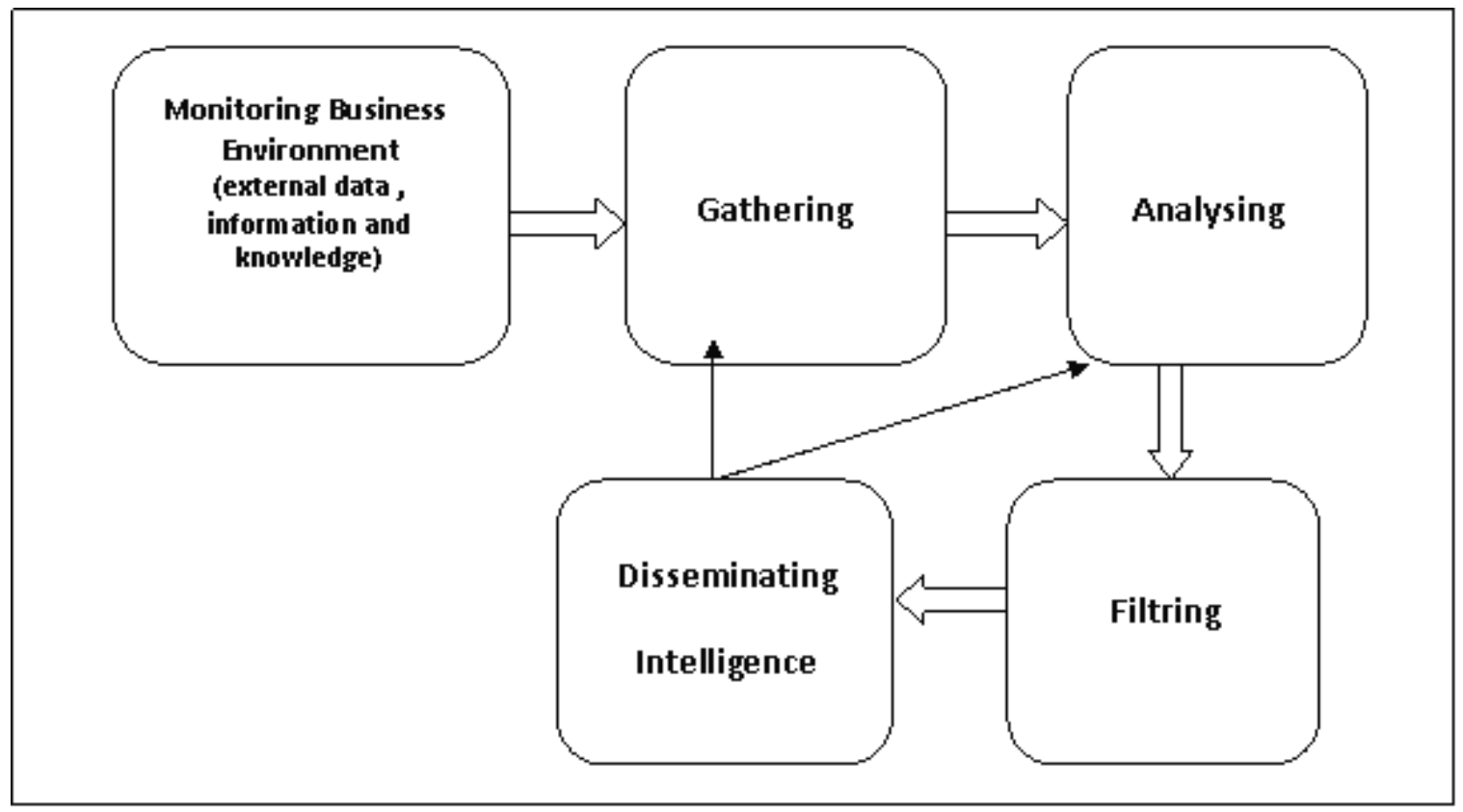

Figure 1: CI process

Many versions of the conceptualization of the CI cycle can be found in the literature. To show their similarities and differences, table 1 presents the basics steps identified by several authors, each of whom divides the CI process into four to six phases. 
Table 1: Models of CI cycle

\begin{tabular}{|c|c|c|c|c|c|}
\hline $\begin{array}{c}\text { Information } \\
\text { Management } \\
\text { Cycle (Cheo, } \\
\text { 2002) }\end{array}$ & CIA (2001) & $\begin{array}{l}\text { Fuld \& Co, } \\
\quad(2002)\end{array}$ & Pirttila (1998) & Kahner(1998) & Miller (2000) \\
\hline $\begin{array}{l}\text { Identification } \\
\text { of information } \\
\text { needs (1) }\end{array}$ & $\begin{array}{l}\text { Planning and } \\
\text { Direction (1) }\end{array}$ & $\begin{array}{l}\text { Planning and } \\
\text { Direction (1) }\end{array}$ & $\begin{array}{l}\text { Definition of } \\
\text { competitor and } \\
\text { information } \\
\text { needs (1) }\end{array}$ & $\begin{array}{l}\text { Planning and } \\
\text { Direction (1) }\end{array}$ & $\begin{array}{l}\text { Identification } \\
\text { on key decision } \\
\text { makers and } \\
\text { intelligence } \\
\text { needs }\end{array}$ \\
\hline \multirow[t]{2}{*}{$\begin{array}{l}\text { Information } \\
\text { acquisition (2) }\end{array}$} & Collection (2) & $\begin{array}{c}\text { Secondary } \\
\text { published } \\
\text { information } \\
\text { sources (2) }\end{array}$ & $\begin{array}{c}\text { Systematic } \\
\text { collection of } \\
\text { competitive } \\
\text { information (2) }\end{array}$ & Collection (2) & Collection (2) \\
\hline & & $\begin{array}{l}\text { Primary source } \\
\text { collection (3) }\end{array}$ & & & \\
\hline \multirow[t]{2}{*}{$\begin{array}{c}\text { Organization } \\
\text { and storage (3) }\end{array}$} & Processing (3) & & \multirow{2}{*}{$\begin{array}{c}\text { Screening } \\
\text { analysis of } \\
\text { collected } \\
\text { information (3) }\end{array}$} & & \\
\hline & $\begin{array}{c}\text { Analysis and } \\
\text { production (4) }\end{array}$ & $\begin{array}{c}\text { Analysis and } \\
\text { production (4) }\end{array}$ & & Analysis (3) & Analysis (3) \\
\hline $\begin{array}{l}\text { Information } \\
\text { production and } \\
\text { services (4) }\end{array}$ & & \multirow{2}{*}{$\begin{array}{l}\text { Report and } \\
\text { information }\end{array}$} & & & \\
\hline $\begin{array}{c}\text { Information } \\
\text { distribution (5) }\end{array}$ & $\begin{array}{l}\text { Dissemination } \\
\text { (5) }\end{array}$ & & $\begin{array}{l}\text { Distribution } \\
\text { related user } \\
\text { groups (5) }\end{array}$ & $\begin{array}{c}\text { Dissemination } \\
\text { (5) }\end{array}$ & $\begin{array}{l}\text { Dissemination } \\
\text { (5) }\end{array}$ \\
\hline $\begin{array}{c}\text { Information } \\
\text { use (6) }\end{array}$ & & & & & \\
\hline
\end{tabular}

The models presented in Table 1 are similar; however, some distinctive dimensions are evident. Regarding the first step, we see that, despite the different titles, each model recognizes the importance of identifying the type of intelligence/information that is needed to begin the process. Although planning should be the starting point of any process, we argue that, in the CI cycle, planning relates mainly to the identification of the intelligence needs that must be fulfilled and of the various activities and analyses that are required to fulfill such needs. Each model also includes a collection or acquisition stage as a second step. Fuld \& Co. differentiates the collection of information in two parts: secondary/published and primary sources. After the collection of information, the only CI cycle that identifies a step related to the processing of information is the CIA model. In comparison to the information management cycle, the organization and storage of information is a step that is regularly overlooked by the CI community. This step is key to an effective information-related system. All CI models presented here include an analysis stage. Although it is not part of the information management model, this stage is an integral part of any intelligence process. Analysis transforms information into intelligence using a variety of techniques. Pirttilä's model, which omits the organization and storage step, includes "screening" in the analysis step.

\subsection{KM processes}

We earlier defined knowledge management as performing the activities involved in discovering, capturing, sharing, and applying knowledge so as to enhance, a cost-effective fashion, the impact of knowledge on the unit's goal achievement. Thus, knowledge management relies on four main kinds of $\mathrm{KM}$ processes. As shown in Figure 2, these include the processes through which knowledge is discovered or captured. It also includes the processes through which this knowledge is shared and applied. These four KM processes are supported by a set of seven KM 
sub-processes, as shown above with one Subprocess - socialization - supporting two KM processes (discovery and sharing). Of the seven KM sub-processes, four are based on Nonaka (1994). Focusing on the ways in which knowledge is converted through the interaction between tacit and explicit knowledge, Nonaka identified four ways of managing knowledge: socialization, externalization, internalization, and combination. The other three KM sub-processes - exchange, direction, and routines - are largely based on Grant (1996) and Nahapiet and Ghoshal (1998).

\section{Discovery \\ - Combination \\ - Socialization}

Figure 2: KM processes

\section{CI and KM benefits for the organization}

\subsection{CI, which advantages for the organization?}

According to Prescott and Bhardwaj (1995), CI practitioners believe CI programs provide the following benefits:

- Influencing actions of decision-makers

- Improving early warning signals

- Identifying new opportunities

- Exploiting competitor vulnerabilities

- Sharing of ideas

- Better serving the company's customers

Prescott and Bhardwaj (1995) argue that these benefits are directly identifiable, although there are no quantitative measures to support this. An improved market position and improved revenue/profits are not directly identifiable since they are "uncertain effects". These benefits fall into the category of bottom-line measures, which are usually the most commonly requested. Simon and Blixt have tried to measure these uncertain effects. They describe the relevant issues to be measured when considering uncertain effects or monetary benefits of a CI program as:
- Quality, relevance, timeliness, and accuracy of intelligence

- Accuracy of data in analysis

- Increasing number of clients and additional business from current clients

- Business success and performance measured by industry benchmarking

CI reveals the state of business, exposes the unknown, and shows how to tackle current market conditions. It helps recognize risks and new market opportunities earlier and act faster. Good CI delivers often surprising truths, gives a head-up on what's coming, and equips the organization with the knowledge to outmaneuver the toughest rivals. Using the accurate and objective knowledge, good CI provides particularly during unpredictable and turbulent time - can gain better control over their business in the future.

\subsection{Benefits of KM}


According to modern approaches, KM is already considered as a key factor in the organization's performance and, the best resource and the only sustainable competitive advantage to individuals and organizations, because it deals with different resources that can aid decision makers in many ways (Keen, 1991). Most commentators writing on the subject highlight the primary purpose of $\mathrm{KM}$ as efficiency and productivity achieved through the reuse and sharing of experience and know-how. Often overlooked is the potentially important goal of promoting quality of work product and practitioner training that can be shown to increase the value of the client service.

KM can serve a wide variety of purposes. According to Petter Gottschalk, of the Department of Technology Management at the Norwegian School of Management, "effective knowledge management pays off in fewer mistakes, less redundancy, quicker problem solving, better decision making, reduced research development costs, increased worker independence, enhanced customer relations, and improved service”.

Table 2: Benefits and challenges of KM

\begin{tabular}{|l|l|}
\hline Benefits of KM & Challenges of KM \\
\hline - Fosters innovation & - Requires full employee participation \\
- Improves efficiency & - Requires constant updating \\
- Improves coordination and efforts & $\begin{array}{l}\text { - Must sort useful knowledge from useless } \\
\text { information }\end{array}$ \\
- Enhances customers and employee & $\begin{array}{l}\text {-KM projects are not always successful in term of } \\
\text { increased profit margins and reduced costs }\end{array}$ \\
- Improve response time & \\
- Rewards employees & \\
- Improves market time & \\
- Responsive to market changes & \\
- Reduces costs & \\
- Encourages free flow of ideas & \\
- Connects geographically dispersed & \\
people (e.g., customers, employees, & \\
suppliers, and consultants) & \\
- Foster collaboration & \\
- Improves information access & \\
- Expertise localization & \\
\hline
\end{tabular}

\section{KM and CI success factors}

\subsection{Key success factors of CI}

According to Stanat (1990) no single system architecture can be found appropriate for developing a successful intelligence program because of cultural and structural issues. CI

process is likely to be unique in each organization. Therefore, there is rarely a similarity between successful CI processes. Despite, some general success factors and guidelines can be mentioned. In fact, CI process should reflect the organizational culture, available resources and goals of each specific company (Gilad, 1985; Fuld, 1997).

\subsubsection{Top management support and participation} The support from top management is considered the most important success factor for CI implementation success. Intelligence operations should have full senior management commitment and an operating mandate from the top. An intelligence strategy must have full support at board level if it is to succeed (Bord, 1997; Kahaner, 1996). It is also essential to make sure top management has the available intelligence at their fingers (Hering, 2000).

\subsubsection{Identifying CI needs}


The company's management must view the $\mathrm{CI}$ as a key resource for better decision-making. This means identifying the impending threats, becoming important and alert management to new business opportunities.

\subsubsection{CI culture/ awareness}

For a company to use its efforts successfully, an appropriate CI culture that support open communication, team spirit, information and knowledge sharing and focus on shared goals, is necessary (Olivier et al., 2003). According to Calof (2000) the attitudes of people when they don't trust CI, and are unwilling to share information is considered a main barrier that prevent firms from effectively gathering and using CI. The organization should develop programs that make people want to share their knowledge and acquire new one (Iivonen and Huotari, 2000; Den Hertog and Hnizeng, 2000).

\subsubsection{CI tools and resources}

A good CI functions must also have adequate resources to deliver the required judgments, insights, and analysis that support the management's decisions. Asking one or more individuals to "take responsibility for the company's CI" requires providing them with the budget and resources for professional development, outsourced research, and technology tools to implement and succeed with a CI process.

\subsection{Key success factors of KM}

$\mathrm{KM}$ covers a wide range of functionalities and support different sets of activities. Some factors are considered critical for the successful implementation.

However, there exist different views among practitioners and researchers on how a KM program can be designed and implemented in organizations. Several studies have proposed several key variables for successful implementation.

\section{KM and CI to achieve competitive advantage}

\subsection{What is meant by competitive advantage?}

Concept of competitive advantage has a long tradition in the strategic management literature. Ansoff (1965) defined it thusly: “(...) (To) isolate characteristics of unique opportunities within the field defined by the product-market scope and the growth vector. This is the competitive advantage. It seeks to identify particular properties of individual product markets which will give the firm a strong competitive position”. 
Table 3: Success factors of KM

\begin{tabular}{|l|l|}
\hline \multicolumn{1}{|c|}{ RESEARCHER } & \multicolumn{1}{|c|}{ SUCCESS FACTOR FOR USING KNOWLEDGE MANAGEMENR } \\
\hline Kuan yen wong (2005) & $\begin{array}{l}\text { Senior management support, culture, information technology, strategy and } \\
\text { goals, measures, organizational infrastructure, activities and processes, } \\
\text { motivational support, resources, education, human resources management }\end{array}$ \\
\hline Mathi (2004) & $\begin{array}{l}\text { Knowledge-based organizations, culture strategy, systems and information } \\
\text { technology infrastructure, systematic and effective process, measures. }\end{array}$ \\
\hline Martins et al. (2003) & $\begin{array}{l}\text { Organisationnel culture, motivation and skills, senior management, structures } \\
\text { ans process, information technology }\end{array}$ \\
\hline Moffett et al. (2003) & $\begin{array}{l}\text { A friendly organizational culture, senior management leadership and } \\
\text { commitment, employee involvement, employee training, trustworthy } \\
\text { teamwork, employee empowerment, information system infrastructure, } \\
\text { knowledge structure }\end{array}$ \\
\hline Reyan and Prybutok (2001) & $\begin{array}{l}\text { An open organizational culture, senior management leadership and } \\
\text { commitment, employee involvement, teamwork, information system } \\
\text { infrastructure }\end{array}$ \\
\hline Devenport et al. (1998) & $\begin{array}{l}\text { Technology infrastructure, organizational infrastructure, balance of flexibility, } \\
\text { evolution and cost-of- accessibility to knowledge, shared knowledge, knowledge } \\
\text { friendly culture, motivated workers who develop, share and use of knowledge. }\end{array}$ \\
\hline Hospal and Fusion (1997) & $\begin{array}{l}\text { Management factors, coordination, control, leadership and measures; factors } \\
\text { related resource : knowledge, people, financial and non-financial resources, } \\
\text { environmental factors : competition, markets, time pressures, economic and } \\
\text { government situation. }\end{array}$ \\
\hline
\end{tabular}

NNN South (1981) defined competitive advantage as the "philosophy of choosing only those competitive arenas where victories are clearly achievable”. Porter (1985) states "competitive advantage grows fundamentally out of value a firm is able to create for its buyers that exceeds the firm's cost of creating it." He argued that a firm's ability to outperform its competitors lay in its ability to translate its competitive strategy into a competitive advantage. Competitive strategy entails positioning the firm favorably in an industry relative to competitors. He confirmed that there are, in general, only two possible competitive advantages a firm may possess, a cost advantage or a differentiation advantage.

Others, particularly proponents of the resourcebased view of the firm (Barney, 1991; Conner, 1991), have extended the definition to include a wider range of possible advantages such as physical capital (Williamson, 1975), human capital (Becker, 1964), technological opportunities and learning (Teece, 1980; 1982; 1986), and organizational capital (Tomer, 1987).
6.2 Synergy between CI and KM to obtain competitive advantage

Knowledge management (KM) is the process through which organizational performance is improved through better management of corporate knowledge. Its goal is to improve the management of internal knowledge processes so that all information required for corporate decisions can be made available and efficiently used. Competitive intelligence (CI) is a process for gathering usable knowledge about the external business environment and turning it into the intelligence required for tactical or strategic decisions. Both KM and CI systems are designed to enhance the information resources of an enterprise, but often target different information types and sources. While CI is concerned with gathering information from the external environment to enable the company to gain competitive advantage (Williams, 2002), most investigation into KM has focused on capturing the knowledge stored within the minds of individual employees (Nidumolu, Subramani, \& Aldrich, 2001). Bagshaw (2000), Johnson (2000), Rubenfeld (2001), and Williams (2002) all focus on the use of KM for collecting, 
managing, and sharing internally generated knowledge.

The combination of effective KM and appropriate CI provide the right mix of the right information to the right decision maker at the right time. Certainly, these two fields are starting to blend into the same melting pot. However, each field has some unique qualities that differentiate it from the other.

Table 4: A comparison between knowledge management and competitive intelligence

\begin{tabular}{|c|c|}
\hline Knowledge Management & Competitive Intelligence \\
\hline -Internal & -External \\
-Reactive & -Proactive \\
- long- term perspective & - short-term and long-term perspective \\
-Technology-based & -Source-based \\
-Dependent on employee & -Environment driven (Political, Economical, Sociological and \\
willingness to contribute & Technological) \\
- knowledge, information & Information, data, knowledge \\
\hline
\end{tabular}

The fields of CI and KM have a number of differences as shown on in the table above, but potential relation can exist if we instinctively regard them in terms of applying enterprise knowledge of the internal and external environment for long-term competitive advantage. The goal of both disciplines is to evaluate the business decisions, locate and deliver appropriate knowledge from within and without the organization and, in the end help to give it meaning and help decision makers.

According to Bensoussan (1996), the keys to a company's future are not found in forecasts, predictions or media gurus, but through patiently, carefully and strategically turning a company's knowledge into competitive intelligence". She identifies the components of CI as available data and expert judgment, and calls for intelligence to be "future-oriented, accurate, objective, relevant, useful, and timely". In other words, each drives the other. As shown earlier in table 3, although there are significant differences in the focus and activities of $\mathrm{KM}$ and $\mathrm{CI}$, they "have similar goals and are natural extensions of one another (e.g., manage information overload and timely/targeted information delivery, provide tools for data analysis, identify subject matter experts, enable collaboration)” (Meta Group, 1998). Davenport (1999) even goes so far as to take the stance that CI can be viewed as a branch or subset of KM.

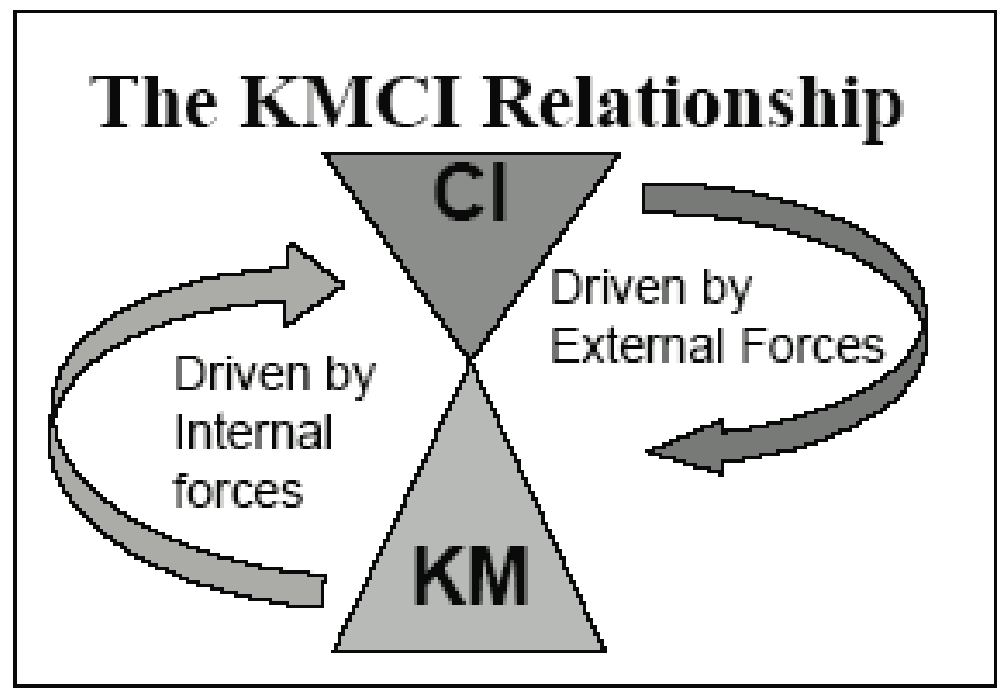

Figure 3: The KMCI relationship. (source: Katherine Shelfer, Drexel University, 2004)

The study conducted by Breeding (2000) at Shell Services International (SII) shows how CI activities at SSI have been impacted by the extensive use of $\mathrm{KM}$. It is demonstrated that 
using the $\mathrm{CI} / \mathrm{KM}$ system gives more time to higher value-added tasks such as simulation, strategy.

\section{Conclusion}

As discussed above, KM and CI are distinct by being both complementary and synergistic. At their core, both fields are concerned with gaining competitive advantage from better applications of information or knowledge. Knowledge may perhaps be the only remaining and one of the most critical sources of competitive advantage available to an organization in the 21st century. This is true; more so, as previously available traditional resources may no longer offer any significant competitive advantage. To remain competitive, organizations must create and use new knowledge. However, the current practices in knowledge acquisition, utilization, and management are mostly limited to capturing, recycling, and deploying the existing information, and making it available on a technology platform. KM and CI are in this regard two important strategies or practices through which organizations could use effective knowledge to improve organizational effectiveness, improve productivity, improve decision making, and especially, obtain a sustainable competitive advantage.

Even if it is difficult to simplify the relationship between CI and KM (Johnson, 1999), it is obvious that the two approaches complement each other. KM and CI are two parts of the same whole because both are designed to apply enterprise knowledge of the internal and external environment for long term competitive advantage. The synergy between KM and CI indicates that greater convergence between the two approaches (Parker and Nitse, 2011).

\section{References}

Bagshaw, M. (2000)” Why knowledge management is here to stay”, Industrial and Commercial Training, 32(5), 179-183.

Becker, G. S. (1964)” Human capital”, New York: Columbia University Press.

Barney, J. (1991) "Firm Resources and Sustained Competitive Advantage," Journal of Management 17(1): 99-120.

Barney, J. (1991) "Organizational Culture: Can It Be a Source of Sustained Competitive Advantage?" Academy of Management Review 11.3 (1986b): 656-65. 1986
Bensoussan, B. and C. Hall. (1996)” The State of Competitive Intelligence in Australia” [online];

www.scipaust.org.au/1996_survey_result_su mmary.

Breedings,B. (2000) "CI and KM convergence: a case study at Shell Services International”, Competitive Intelligence Review, 11(4) 1224.

Civi, E.(2000) "Knowledge management as a competitive asset: A review”. Marketing Intelligence and Planning, 18(4), 166-174.

Conner, K. R., and Prahalad, C. K. (1996)”A resource-based theory of the firm: Knowledge versus opportunism”. Organization Science, 7: 477-501.

Davenport, T.H., De Long, D.W., and Beers, M.C., [1998], Successful Knowledge Management Projects, Sloan Management Review, (77)2 Winter, pp 43 - 57

Davenport, T. (1994). Saving ITs Soul: Humancentered Information Management. Harvard Business Review, 72(2), 119-131.

Davenport, T., Delong, D.W and Beers, M.C (1998) " successful knowledge management projects”, Sloan Management Review, Vol.39, N²? 43-57.

Davenport T. H. (1999)"Knowledge Management and the Broader Firm: Strategy, Advantage, and Performance in Knowledge Management” Handbook (eds. Liebowitz, J.), Boca Raton, Fla.: CRC Press.

Davis, M. (2004)" using business intelligence for competitive advantage”, available at: www.knowledgepoint.com.au/business_intel ligence/Articles/BI_MD001b.htm.

Deeds, D.L. and C. Hill. 1996. Strategic Alliances and the Rate of New Product Development: An Empirical Study of Entrepreneurial Biotechnology Firms. Journal of Business Venturing 11: 41-55.

Drucker, P (1994), Theory Of The Business, Harvard Business Review, SeptemberOctober, pp 95- 106, B oston, M ass, USA.

Fuld and Co (2002). Intelligence Software : the Global Evolution Fuld \& Co Cambridge, (online)

Gilad B. and Gilad T. (1985)” a systems approach to business intelligence”, Business Intelligence Horizons, Vol.28 N5,65-70

Gottschalk P.(1999) 'Use of IT for Knowledge Management in Law Firms," 1999 The Journal of Information, Law and Technology (JILT), http://elj.warwick.ac.uk/jilt/993/gottschalk.html. 
B.Gupta, L. S. Iyer, and J. E Aronson, (2000) "Knowledge management: Practices and challenges". Industrial Management and Data Systems, 100(1), 17-21.

Jafari et al.(2007) "knowledge management in Iran Aerospace Industries: A study on critical factors”, Aircraft Engineering And Aerospace Technology, 79 (4), 375-389.

Johannessen, J. and Olsen, B. (2003)" Knowledge management and sustainable competitive advantages: The impact of dynamic contextual training”. International Journal of Information Management, 23, 277-289.

Johnson, A.R. (1999) "You say Competitive Intelligence and Knowledge Managementtwo parts of the same whole”. Knowledge Management Magazine, 3(3).

Johnson, A.R. (2000)” Competitive intelligence and competitor analysis as knowledge management applications. In J.W. Cortada \& J.A. Woods (Eds.), The Knowledge Management Yearbook 2000-2001 (pp. 8597). Woburn, MA: Butterworth-Heinemann.

Kahaner, L. (1996)” Competitive intelligence: from black ops to boardrooms. How businesses gather, analyze, and use information to succeed in the global marketplace”. New York: Simon \& Schuster.

Shelfer, K. (2004) "The Intersection of Knowledge Management and Competitive Intelligence: Smartcards and Electronic Commerce." Knowledge Management: Lesson Learned: What Works and What Doesn’t. Eds. Michael E. D. Koenig and T. Kanti Srikantaiah. New Jersey: Information Today, Inc,. 419-42.

Keen, P. G. W. (1991)"shaping the Future" Boston: Harvard Business School Press.

King, A. W., \& Zeithaml, C. P. (2001). Competencies and firm performance: Examining the causal ambiguity paradox. Strategic Management Journal, 22, 75-99.

Lado, A. A., \& Wilson, M. C. (1994). Human resource systems and sustained competitive advantage: A compentency-based perspective. Academy of Management Review, 19(4), 699-727.

Mertino, K., Heisig, P. and Vorbeck, J. (2003) "knowledge management: concepts and practices”, Spring, New York, NY.

McInerney.C and Koenig M. "Synthesis Lectures on Information Concepts, Retrieval, and Services”, January 2011, Vol. 3, No. 1 , Pages 1-96
Meta Group, Inc (1998)”Applying KNOWLEDGE management to competitive intelligence" retrived May 2001 from: http//www2.megagroup.com/product/insight /aims_6_res.htm

Miller, J. 2000. Millennium intelligence: understanding and conducting competitive intelligence in the digital age. New York: Cyberage Books.

Nahapiet, J. and Ghoshal, S.(1998)"Social capital, intellectual capital, and the organizational advantage”. Academy of Management Review, 23: 242-266

Nidumolu, S.R., Subramani, A. and Aldrich, A. (2001)" Situated learning and the situated knowledge web: exploring the ground beneath knowledge management”, Journal of Management Information Systems 18(1), 115-150.

Nonaka. I (1994) “A Dynamic Theory of Organizational Knowledge Creation," Organization Science 5:1 February page 1437.

Nonaka, I and Takeuchi, H (1995) "The knowledge creating company: how Japanese companies create the dynamics of innovation “, New York: Oxford University Press, page. 284 ,

Ofek, E. and Sarvary, M.(2001) "leveraging the customer base: creating competitive advantage through knowledge management”, Management Science , 47, 11 (Nov), page 1141-56.

Olivier et al. (2003)"'legal goodness for the collection of information in the competitive intelligence process in South Africa», South Africa Journal, Vol.5(4), December.

Parker,K.R and Nitse, P.S(2011) "Competitive Intelligence gathering”, Encyclopedia of Knowledge Management, Information Science Reference, New York, 2011 :103111.

Prahalad, C.K. and Hamel G. (1990) "The core competence of the corporation ", Harvard Business Review, n 3,79-91.

Prescott, J.E. and P.T. Gibbons. (1992a). "The parallel process of competitive intelligence: Why it exists and what we can do about it? Competitive Intelligence Review, summer, 3, 2: 11-13.

Prescott, J.E. (1999). "Debunking the Academic Abstinence Myth of CI," Competitive Intelligence Magazine 2(4): 22-26.

Porter, M.E. (1985)" Competitive advantage, creating and sustaining superior performance, New-York: Free Press 
Prescott, J. and G. Bhardway. 1995. A survey of competitive intelligence practices. Competitive Intelligence Review, 6,2: page 4-14.

Prescott, J.E., and Bhardwaj, G. (1995) "Competitive intelligence practices: a survey”, Competitive Intelligence Review, Vol. 6 No. 2, pp. 4-14..

Prescott, J.E., and Gibbons P.T.( 1996), "The seven seas of global Competitive intelligence”, Competitive Intelligence Review, Vol. 7 No. 1, pp. S41-8.

Rubenfeld, J. (2001)” Knowledge management for life: Make the world a better place”. Ubiquity, 2(41).

Williams, R. (2002)” Applying KM lessons to competitive intelligence: Creating a userdriven competitive intelligence culture”. Retrieved March 2003 from http:// old.apqc.org/free/ articles/dipArticle.Cfm?ProductID=1493

Sammon, W.L., M.A. Kurland, and R. Spitalnic. (1984) "Business Competitor Intelligence: Methods for Collecting Organizing and Using Information”. New York: John Wiley \& Sons.

SCIP. (2000), Society of competitive intelligence professionals.

(Online). http://www.scip.com.

Shelfer, K. (2004) "The Intersection of Knowledge Management and Competitive Intelligence: Smartcards and Electronic Commerce." Knowledge Management: Lesson Learned: What Works and What Doesn't. Eds. Michael E. D. Koenig and T. Kanti Srikantaiah. New Jersey: Information Today, Inc, 2004. 419-42

Simon, N. and A. Blixt. (1996)” Navigating in a Sea of Change”. Alexandria, VA: Society of Competitive Intelligence Professionals.

South, S.E. (1981) "Competitive Advantage: The Cornerstone of Strategic Thinking,” Journal of Business Strategy 1(4): 15-25.

Stanat R. (1990)” The Intelligent Corporation: creating a shared network for information and profit”, New York, Amacom.

Teece, D. J. (1980)"Economics of scope and the scope of the enterprise”, Journal of Economic Behavior and Organization, 1, pp. 223-247

Teece DJ. (1982) "Towards an economic theory of the Multiproduct firm”, Journal of Economic Behavior and Organization 3(1): 39-63.
Teece DJ. (1986)” Profiting from technological innovation”. Research Policy 15(6): 285305.

Williams, S. W. (2002)” Making better business decisions: Understanding and improving critical thinking and problem solving skills”, Thousand Oaks, CA: Sage Publications.

Wernerfelt, B., (1984” A Resource-Based View of the Firm", Strategic Management Journal, 171-180

K. Y Wong,. \& E. Aspinwall. "Characterizing knowledge management in the small business environment". Journal of Knowledge management, 8(3), 44-61., pp. 123-135. 1993

Williamson, O. E (1975)” Markets and Hierarchies: Analysis and antitrust implications”, The Free Press, New York

Wong, Y.K (2005) “critical success factors for implementing knowledge in small and medium enterprise”, Industrial Management And Data Systems, Vol.105 N³,261-279. 